\title{
ENVIRONMENTAL ASSESSMENT \\ FOR THE STRATEGIC PETROLEUM RESERVE \\ BIG HILL FACILITY \\ STORAGE OF COMMERCIAL \\ CRUDE OIL PROJECT
}

Jefferson County, Texas

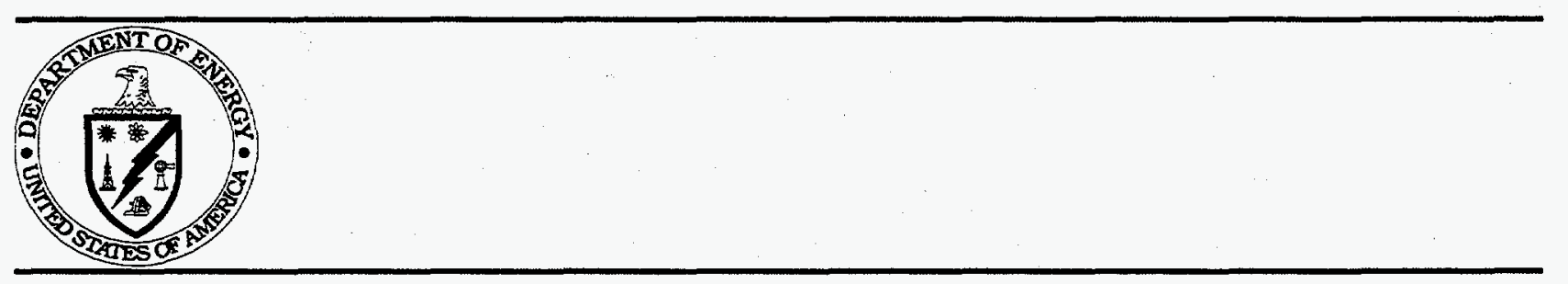

U.S. Department of Energy

New Orleans, LA 70123

March 1999 


\section{DISCLAIMER}

This report was prepared as an account of work sponsored by an agency of the United States Government. Neither the United States Government nor any agency thereof, nor any of their employees, make any warranty, express or implied, or assumes any legal liability or responsibility for the accuracy, completeness, or usefulness of any information, apparatus, product, or process disclosed, or represents that its use would not infringe privately owned rights. Reference herein to any specific commercial product, process, or service by trade name, trademark, manufacturer, or otherwise does not necessarily constitute or imply its endorsement, recommendation, or favoring by the United States Government or any agency thereof. The views and opinions of authors expressed herein do not necessarily state or reflect those of the United States Government or any agency thereof. 


\section{DISCLAIMER}

Portions of this document may be illegible in electronic image products. Images are produced from the best available original document. 


\section{FINDING OF NO SIGNIFICANT IMPACT FOR STORAGE OF COMMERCIAL CRUDE OIL AT THE STRATEGIC PETROLEUM RESERVE (SPR) BIG HILL FACILITY}

The Department of Energy (DOE) has prepared an Environmental Assessment (EA), DOE/EA 1289 for the proposed storage of up to 70 million barrels of commercial crude oil in unused cavern storage space at DOE SPR Big Hill Facility in Jefferson County, Texas.

The proposed action complies with initiatives to increase the cost efficiency of the SPR by leasing underused storage capacity and also presents an opportunity to augment crude oil supplies for strategic purposes by receiving storage fees in the form of crude oil.

Based on the analysis in DOE/EA 1289, DOE has determined that this proposed action is not a major Federal action significantly affecting the quality of the human environment within the meaning of the National Environmental Policy Act of 1969 (42 U.S.C 4321, et seq.). Therefore, the preparation of an Environmental Impact Statement is not required, and DOE is issuing this Finding of No Significant Impact.

Issued at New Orleans, this 26 th day of March 1999.

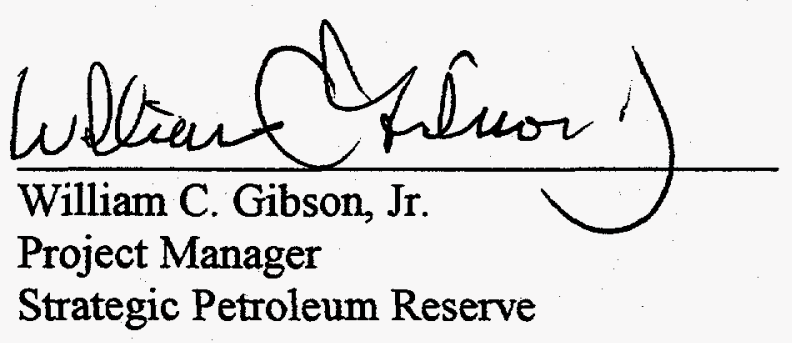




\section{TABLE OF CONTENTS}

Page

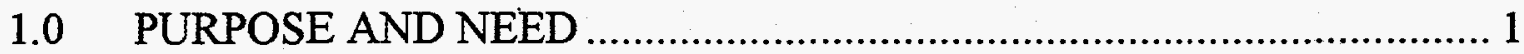

2.0 DESCRIPTION OF THE PROPOSED ACTION

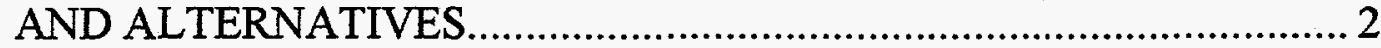

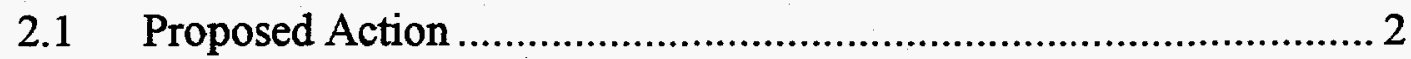

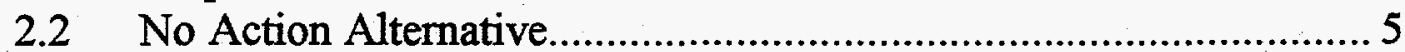

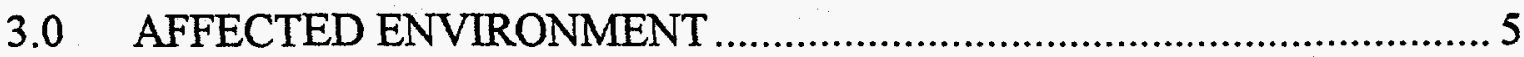

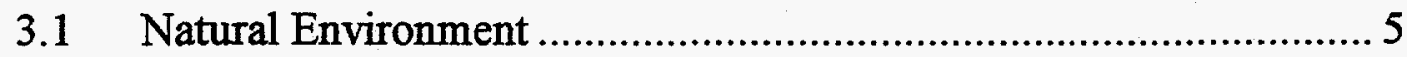

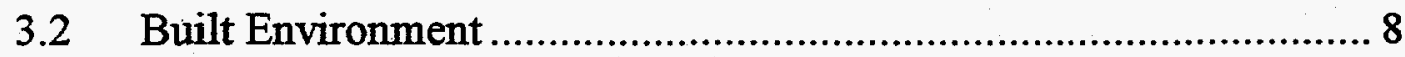

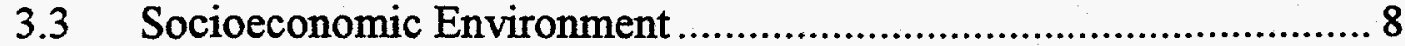

3.3.1 Demographics for Environmental Justice Concerns .............. 8

3.3.2 Emergency Preparedness and Spill Response........................ 9

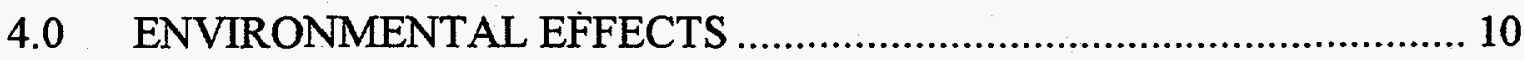

4.1 Impact on Water Resources ..................................................... 10

4.2 Impact on Air Quality ........................................................... 10

4.3 Impact on Endangered or Threatened Species............................... 11

4.4 Impact on Floodplains and Wetlands ......................................... 11

4.5 Impact on Farmland, State or National Parks, Wild and Scenic Rivers, Natural Resources.......................................... 11

4.6 Impact on Socioeconomic Environment...................................... 12

4.7 Other Impacts ...................................................................... 12

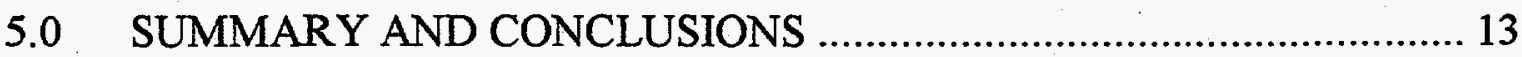

6.0 AGENCIES AND PERSONS CONSULTED .................................... 14

7.0 REFERENCES

\section{FIGURES}

Figure 1, Locations of SPR Facilities ................................................................. 3

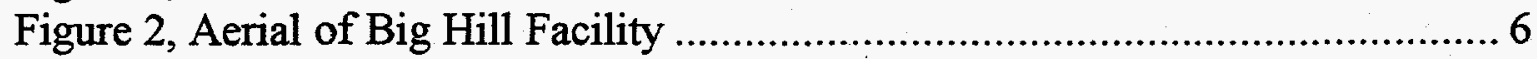




\subsection{PURPOSE AND NEED}

The Energy Policy and Conservation Act of 1975 (EPCA) as amended authorizes the creation of the Strategic Petroleum Reserve (SPR) to store crude oil to reduce the United States' vulnerability to energy supply disruptions. Currently, the SPR contains approximately 561 million barrels of oil (down from a 1994 peak of 592 million barrels) in four storage facilities in Texas and Louisiana.

EPCA allows the Department wide latitude in its methods for acquiring oil, stating in subsection 160(a)(3) that "the Secretary is authorized...to place in storage, transport, or exchange...petroleum products acquired by purchase, exchange, or otherwise." The Department is considering ways that would add to the petroleum stockpile without requiring additional outlays of Federal dollars.

The proposed action is to enter into contracts with commercial entities to store their crude oil in unused cavern storage space at the U.S. Department of Energy (DOE) SPR Big Hill Facility. Storage fees would be paid in crude oil which would be left in the Reserve. The SPR would make available 70 million barrels of unfilled space in six caverns at its Big Hill Facility in Jefferson County, Texas. This volume would be sufficient in scope and magnitude to acquire substantial quantities of oil for the Government, provide low-cost commercial storage, and increase energy security for the Nation.

Congress has not authorized purchase of crude oil to refill the Reserves since 1990. The proposed action presents an opportunity for the SPR to augment crude oil supplies as much 30 million barrels over a ten year commercial storage period.

The proposed action complies with initiatives to increase the cost efficiency of the SPR by leasing underused storage space. The SPR currently has 120 million barrels of unused capacity. In exchange for use of the unused capacity, industry will pay storage fees in the form of crude oil which will be an innovative method of filling the strategic reserves and increasing the amount of crude oil available to respond to oil supply shortages.

The proposed action is consistent with the 1998 SPR Strategic Plan initiatives to sell or lease SPR facilities that are not required for standby operational readiness provided there is no adverse consequences to the SPR mission or program. This Environmental Assessment describes the environmental impacts of this approach. 


\subsection{DESCRIPTION OF THE PROPOSED ACTION AND ALTERNATIVES}

\subsection{Proposed Action}

The SPR currently has nearly 120 million barrels of underutilized storage capacity: 78 million barrels at the Big Hill site; 5 million barrels at the Bryan Mound Site; 26 million at the West Hackberry site; and 7 million at the Bayou Choctaw site. The Big Hill and Bryan Mound sites are in Texas and the West Hackberry and Bayou Choctaw sites are in Louisiana. The proposed action currently being considered is to enter into contracts with commercial interests to utilize some of the storage capacity. In exchange for the use of the storage capability, industry will pay storage fees in the form of crude oil rather than dollars which will increase the amount of Government-owned crude oil available to respond to a national energy supply disruption. Over a 10-year period, the SPR could conceivably acquire title to nearly 30 million barrels of crude oil.

In order to maximize the commercial sector interest in storing oil in the SPR, the SPR has issued a request for offers for the Big Hill site (February 17, 1999), that is very flexible as to the quantity, quality, length of storage, type of storage, and other terms. It is not possible to precisely describe the details of the storage services that the SPR may ultimately contract to provide because the offers have not yet been received and contracts have not been negotiated. Therefore it is necessary to describe a range of possible outcomes to the solicitation process in order to fully describe the proposed action for National Environmental Policy Act (NEPA) purposes.

The current Request for Offers for commercial storage services has been offered at one site, the Big Hill site. Other sites with underutilized storage capacities have not been offered at this time. The Big Hill site currently has six empty storage caverns with a total storage capacity of 70 million barrels. For segregated storage, each cavern would hold the crude oil of a single owner. If storage is commingled, the crude oil of multiple owners, including the SPR, could be mixed in one or more caverns. Commingling offers operational flexibility that would allow the caverns to be filled and drawn down at higher rates.

The commercial customer's crude oil would be delivered to the Big Hill site by either pipeline or a combination of vessel and pipeline which is the same manner SPR oil is delivered. Big Hill connects to Sun Marine Terminal with a 24.44-mile, 36-inch pipeline. Big Hill also connects to the Unocal Terminal with a 2-mile, 24-inch pipeline which ties into the above pipeline. The above Big Hill pipeline also has a connection to the 20 -inch Equilon pipeline to Houston, Texas. 
BIG HILL

GENERAL LOCATION

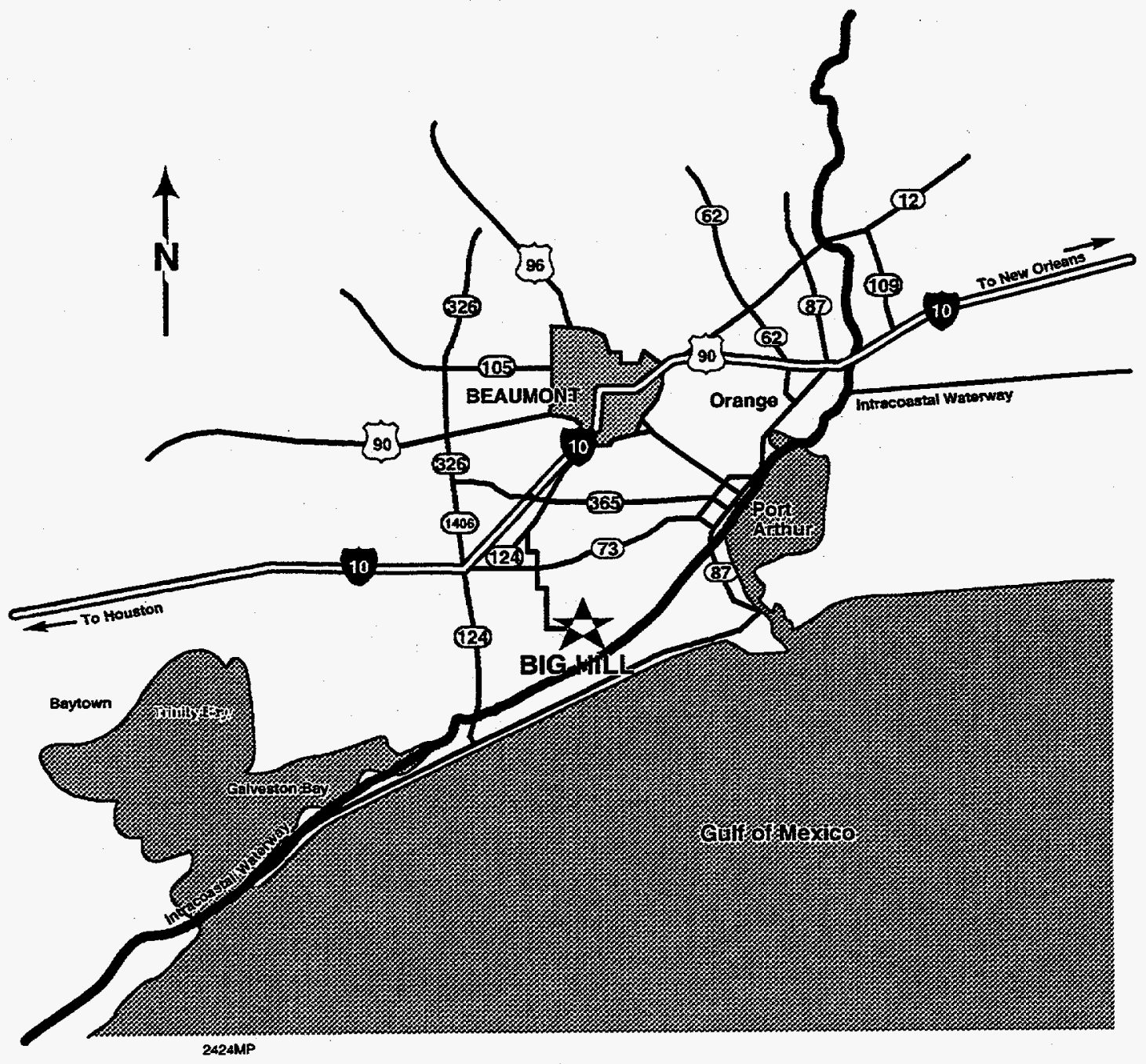

Figure 1. Location of SPR Facilities 
Fill of the 70 million barrels of storage would occur at 150,000 barrels per day assuming segregated storage and no commercial customer taking more than one storage cavern. If a single customer contracts for space in more than one cavern, or proposes commingled storage, then fill may be increased to 200,000 barrels per day.

Drawdown and delivery to the commercial customer would also occur either by pipeline or vessel. Assuming segregated storage with a single customer renting no more than a single cavern, drawdown would be limited to 150,000 barrels per day. A single customer renting more than a single cavern (or commingled storage) could result in a drawdown rate of approximately 320,000 barrels per day.

Final contract negotiations will determine how long the oil will remain in storage. This could range from one or more caverns for less than 1 year to all caverns for 10 years. The amount of time that commercial crude oil will be stored is affected by a number of factors. Given the fill and delivery capacity constraints discussed earlier, the more oil placed in storage, the fewer times the oil can be cycled in and out. Using all six caverns would allow for a maximum of 70 million barrels to be filled in about 350 days and withdrawn in about 218 days. This would potentially allow for approximately six cycles in a 10-year period. The amount cycled would be reduced by the amount of crude oil owed to the Government for storage fees.

If the maximum number of fills and withdrawls occurs, two new caverns and perhaps a brine pond may be required to continue to operate the facility. These would be located on the SPR site or on acquired land near the site. If these actions become necessary, they will be addressed in a separate NEPA review in subsequent years.

Nearly 20 years of SPR operations have shown that the storage of crude oil for more than 5 years in underground caverns can result in the migration of gases, principally methane, into the caverns where the gasses become dissolved in the stored oil. Additionally, thermal heating of the oil occurs raising the receipt temperature of 75 degrees Fahrenheit $\left({ }^{\circ} \mathrm{F}\right)$ to as high as $135^{\circ} \mathrm{F}$. This influx of gas and increase temperature raises the crude oil vapor pressure above limits required by safety and emission guidelines for a drawdown. The SPR has developed processes for cooling and degasifying the oil. The environmental consequences of degasifying SPR oil was assessed in the Environmental Assessment of Oil Degasification at Four SPR Facilities in Texas and Louisiana in September 1994 (DOE/EA0954). Since the negotiated contracts for commercial storage may extend for 10 years or longer, the proposed action includes the potential for 
degasification of the commercial crude oil which will require installation of degasifying units.

\subsection{No Action Alternative}

The No Action alternative to the proposed action is to not award any contracts for the commercial storage of crude oil in the SPR. Storage would be limited to either U.S. Government-owned oil or long-term strategic storage for foreign governments under authority of the Balanced Budget Act of 1997, 42 USC 6247a.

The available storage capacity would remain underutilized and deprive the Government of the benefits of commercialization that would have increased the quantity of crude oil available to respond to a national emergency without having to purchase crude oil on the commercial market.

\subsection{AFFECTED ENVIRONMENT}

A detailed description of the environment and operations of the Big Hill Facility can be found in U.S. Department of Energy, Strategic Petroleum Reserve-Texoma Group Salt Domes, Environmental Impact Statement, DOE/EIS-0029 dated in 1978.

\subsection{Natural Environment}

The Big Hill site is located in Jefferson County, Texas, approximately 109 kilometers ( $\mathrm{km})$ (68 miles) east of Houston, $37 \mathrm{~km}$ (23 miles) southwest of Port Arthur, and $14 \mathrm{~km}$ (9 miles) north of the Gulf of Mexico. Only small unincorporated communities are located near the site. The rural area around the site (Figure 2) is used primarily for rice farming, cattle grazing, and oil and gas production. The permanent work force is supplied in small part from the local area, with the remainder moving into the area or commuting from Beaumont or Port Arthur. The site is situated on approximately 111 hectare (275 acres) of land on the Big Hill salt dome. Surface elevations reach 10 meters ( $35 \mathrm{feet}$ ) above sea level, the highest elevations in the region. The agricultural and pasture land uses around Big Hill are typical of the region.

As authorized by the Clean Air Act, the U.S. Environmental Protection Agency (EPA) has established National Ambient Air Quality Standards (NAAQS) for six criteria pollutants: carbon monoxide (CO), sulfur dioxide $\left(\mathrm{SO}_{2}\right)$, nitrogen dioxide $\left(\mathrm{NO}_{2}\right)$, ozone $\left(\mathrm{O}_{3}\right)$, lead $(\mathrm{Pb})$, and particulate matter smaller than 10 micrometers (PM10). Because ozone generally is not emitted directly but is formed in the atmosphere by photochemical reactions of $\mathrm{NO}_{2}$ and volatile organic compounds (VOC), strategies to 
attain and maintain the ozone NAAQS typically involve reducing area-wide $\mathrm{NO}_{2}$ and VOC emissions. The primary NAAQS specify ambient concentrations of these pollutants that are protective of the public health, while secondary NAAQS specify ambient concentrations that are protective of welfare (e.g., property, etc.). EPA classifies areas that exceed NAAQS for one or more of the six criteria pollutants as non-attainment areas for that particular pollutant or pollutants.

Table 1

Ozone Non-attainment Classifications

\begin{tabular}{|l|c|c|}
\hline \multicolumn{1}{|c|}{ Class } & $\begin{array}{c}\text { Design Value } \\
(\mathbf{p a r t s} \text { per million } \\
(\mathbf{p p m})\end{array}$ & Attainment Date \\
\hline Marginal & $0.12-0.138$ & 1993 \\
\hline Moderate & $0.138-0.160$ & 1996 \\
\hline Serious & $0.160-0.180$ & 1999 \\
\hline Severe & $0.180-0.280$ & $2005 / 2007$ \\
\hline Extreme & $0.280+$ & 2010 \\
\hline NAAQS & 0.12 & \\
\hline
\end{tabular}

Source: Section 181(a), Clean Air Act Amendments of 1990

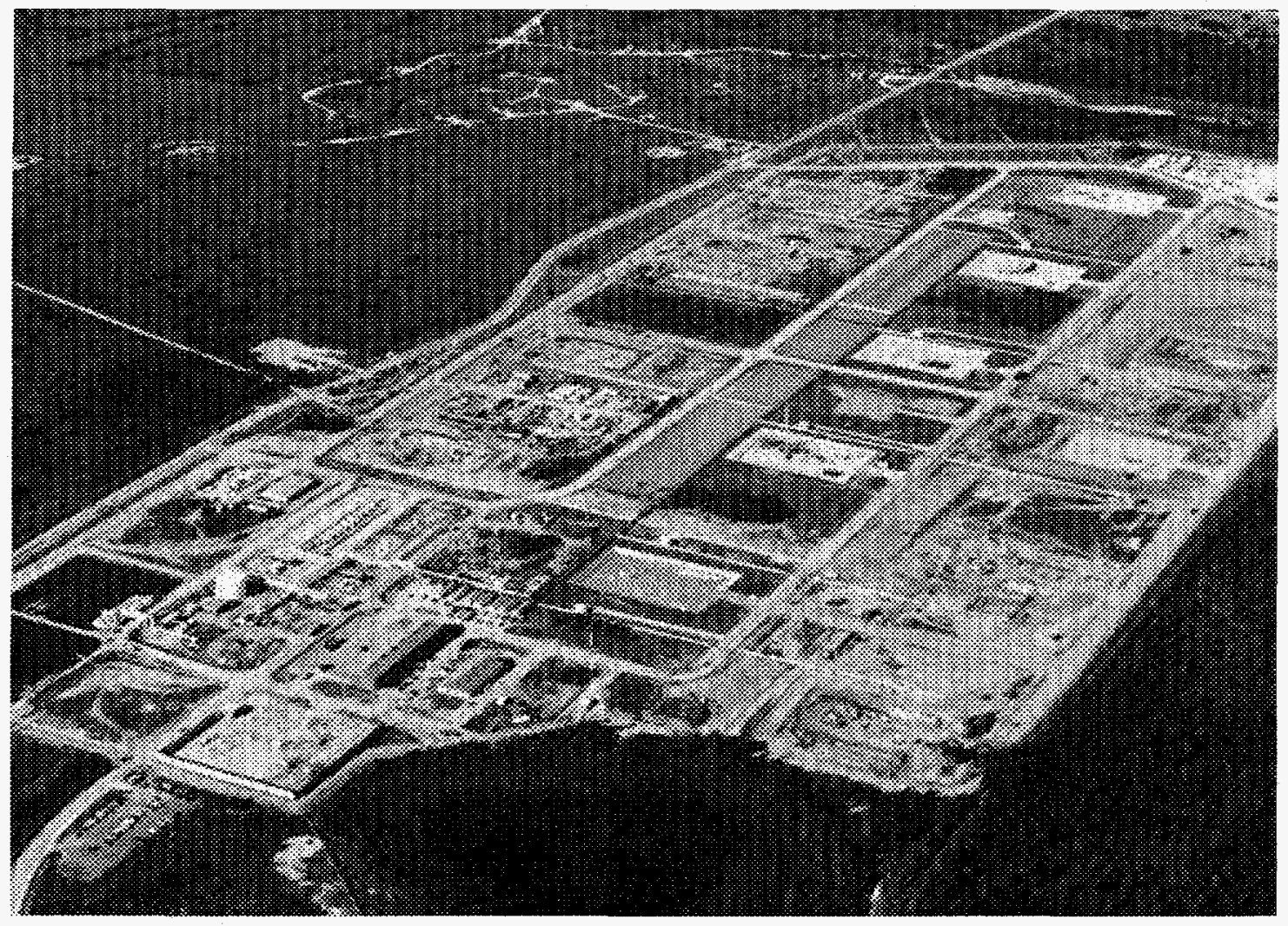

Figure 2. Aerial of Big Hill Facility 
To facilitate pollution control planning, the Clean Air Act authorizes the EPA Administrator to subdivide each State into Air Quality Control regions (AQCRs); a State may then alter the boundaries of the AQCRs with the approval of the Administrator. Any State in which a non-attainment area is located must submit a State Implementation Plan (SIP) to reduce the concentration of all pollutants to the acceptable level in the AQCR containing the non-attainment area. The State must design the SIP to bring the area to attainment status within a statutorily established time frame.

Based on 40 Code of Federal Regulations (CFR)Part 81, "Designation of Areas for Air Quality Planning Purposes," Jefferson County is in a moderate non-attainment area for ozone. The Big Hill Facility is not classified as a major source for regulated air pollutants during any operational phase. Table 2 depicts the current thresholds for major sources and major modifications for moderate non-attainment areas in the State of Texas.

Table 2

Major Source Emission Thresholds (for Moderate Non attainment Areas)

\begin{tabular}{|l|c|c|}
\hline Pollutant & $\begin{array}{c}\text { Major } \\
\text { Source } \\
\text { tons/year }\end{array}$ & $\begin{array}{c}\text { Major } \\
\text { Modification } \\
\text { tons/year }\end{array}$ \\
\hline Ozone & 100 & 40 \\
\hline $\mathrm{CO}$ & 100 & 100 \\
\hline $\mathrm{SO}_{2}$ & 100 & 40 \\
\hline $\mathrm{PM} 10_{\mathrm{NO}_{2}}$ & 100 & 15 \\
\hline Lead & 100 & 40 \\
\hline
\end{tabular}

The upland habitat, which comprises the majority of the site, consists of many tall grasses such as bluestem, indiangrass, switchgrass, and prairie wildgrass. A few 150-year-old live oak trees are present on the site. Identified bird concentrations and rookeries are about $8 \mathrm{~km}$ ( 5 miles) south and west of the site. There are two ponds present on the eastern edge of the dome, one of which is located on the northeast corner of the site and the other just north of the site.

Approximately $1 \mathrm{~km}(0.6$ miles) south of the dome is the northern boundary of fresh to intermediate marsh which grades into brackish and saline marsh toward the Gulf of Mexico. The nearby waterways include Spindletop Ditch, approximately 3 miles south of the site, which connects to the Intracoastal Waterway located 2 miles further south and oriented in a 
northeast to southwest direction. Freshwater impoundments are located south of the site. Numerous sloughs, bayous, and lakes, including Willow Slough Marsh, Salt Bayou, Star Lake, and Clam Lake, connect with the Intracoastal Waterway. Natural ridges (cheniers) paralleling the coastline isolate the marsh from the Gulf of Mexico. Existing habitats in the vicinity of the site are related to agricultural use. There are petroleum-related industrial operations on and off the salt dome which have altered land use.

No rare, threatened, or endangered species habitat is identified in the vicinity of the Big Hill site on the Texas Natural Resource Conservation Commission (TNRCC), Coastal Regional Spill Response Map. The paddlefish, a state regulated species, has been identified in Taylor Bayou in the vicinity of the oil pipeline crossing. Fauna typical in the area include coyote, pocket gopher, rabbit, raccoon, rodents, snakes, turtle, and numerous upland game birds and songbirds. The nearby ponds and marsh south of the site provide excellent habitat for the American alligator. The McFaddin National Wildlife Refuge, located approximately $5.6 \mathrm{~km}(3.5$ miles) south-southeast of the facility, provides important habitat for overwintering waterfowl.

\subsection{Built Environment}

The Big Hill site capacity is 160 million barrels of crude oil in 14 caverns, and the 1998 year-end inventory is $\mathbf{8 1 . 5}$ million barrels. Appurtenant facilities include a raw water intake structure $8.4 \mathrm{~km}$ ( 5.2 miles) south on the Intracoastal Waterway with a 48 -inch raw water intake pipeline extending to the site, a 48-inch brine disposal pipeline extending $15 \mathrm{~km}(9.4$ miles) onshore and $7.6 \mathrm{~km}$ ( 4.7 miles) offshore in the Gulf of Mexico, and a $39.3 \mathrm{~km}$ (24.4-mile) 36-inch pipeline for transporting crude oil between the site and the Sunoco Terminal in Nederland, Texas. The brine pipeline has a series of 72 brine diffuser nozzles which disperse and mix brine with receiving sea water.

\subsection{Socioeconomic Environment}

\subsubsection{Demographics for Environmental Justice Concerns}

Based on information from the U.S. Bureau of the Census, the population in Jefferson County, Texas was 239,389 in 1990 with estimates of 241,940 in 1997 . Of this total, approximately 41 percent of the population is estimated to be minorities. Table 3 shows the estimated population for various minorities within the County. 
Table 3

Racial Composition in Jefferson County, Texas

\begin{tabular}{|l|c|}
\hline \multicolumn{1}{|c|}{ Race } & 1997 Estimate \\
\hline White & 59 Percent \\
\hline African American & 31 Percent \\
\hline Hispanic & 6 Percent \\
\hline Asian & 3 Percent \\
\hline American Indian & $<1$ Percent \\
\hline
\end{tabular}

The Big Hill facility employed about 96 people in 1998 from the surrounding area at an average annual salary of $\$ 47,000$. The estimated median household income in Jefferson County, Texas in 1995 was $\$ 30,209$.

\subsubsection{Emergency Preparedness and Spill Response}

DynMcDermott Petroleum Operations Company (DM), the prime contractor on the SPR, maintains an emergency response plan entitled Emergency Response Procedures: Big Hill that provides a detailed overview of the operational requirements during an emergency. The document describes in detail the overall emergency response process, the roles and responsibilities of individuals in an emergency, and the guidelines and procedures for specific scenarios.

The Big Hill facility operates under the Texas General Land Office Oil Spill Prevention and Response Act and the Oil Pollution Act of 1990. It recently passed an Oil Pollution Act inspection by the EPA in January 1999 without any deficiencies, and complies fully with the Texas Railroad Commission Rule 95 that establishes safety requirements for storage of hydrocarbon liquids in salt formations. The Big Hill Facility also conducts spill response drills and exercises in accordance with the National Preparedness for Response Exercise Program (PREP) Guidelines. The facility is also a member of local area response organizations.

The Big Hill Facility has averaged 18.97 million barrels of crude oil transfers and 16.8 million barrels of brine transfers per year since 1993 without a reportable crude oil or brine spill. Reportable spills are promptly reported to the State and Federal agencies. 


\subsection{ENVIRONMENTAL EFFECTS}

\subsection{Impact on Water Resources}

During drawdown, raw water from the Intracoastal Waterway will be required to displace the crude oil out of the caverns into the pipeline distribution system. The Big Hill facility is currently permitted by the TNRCC to use 30,000 acre-feet (232 million barrels) of water from the Intracoastal Waterway. In 1997, only 1,060 acre-feet were used for normal operations. Commercialization of the Big Hill facility will increase the water usage over the current level but it is not anticipated that it will be greater than the permitted limit.

The impact on surrounding surface water and groundwater from SPR operations at the Big Hill facility has been monitored every month since 1987. There is monitoring data that the SPR operations have had a negligible impact on the surrounding surface waters and groundwater in and around the facility. Big Hill has operated for more than 10 years with a positive compliance history of the facility in regards to its permitted stormwater and waste water discharges. With the increase in crude oil transfers to and from the facility as a result of commercialization, there would be a proportional increase in probability of spills, release events, and noncompliances. However, these would not be more environmentally traumatic than events assessed in the previous Environmental Impact Statements. Based on the SPR operating history, the effects on the surrounding surface water and groundwater will continue to be minor.

\subsection{Impact on Air Quality}

The impact on air quality as a result of operations at the Big Hill facility has been negligible in this region. The facility is currently permitted to emit 15 tons per year of VOC from such sources as the brine pond, piping components, and miscellaneous small sources that include tanks and diesel generators.

The largest increase in regulated pollutants as a result of the proposed project would be an increase in the VOC emissions from the brine pond. The other sources are not directly affected by an increase in crude oil and brine transfers. As the caverns are filled up with crude oil, brine from the caverns is displaced into the brine pond. Approximately $2 \mathrm{ppm}$ of VOC is trapped in the brine and released into the atmosphere as the brine settles in the pond. The estimated VOC emissions increase from transferring 70 million barrels of crude oil per year is 29.40 tons per year. These estimated emission were calculated as follows: 
VOC (tons per year) $=$ VOC concentration in brine $\left(\mathrm{ppm} \times 10^{-6}\right) \times$ Volume of brine into pond (million barrels) $x 42$ (gallon/barrel) $x$ Brine Density (pound/gallon)

VOC (tons per year) $=2 \times 10^{-6} \times 70$ million barrels $\times 42 \times 10=29.40$ tons per year

Under normal operating conditions, the VOC emissions from the brine pond are about 3.15 tons per year. Therefore, there will be an increase in VOC emissions with the proposed project. However, the increase is still below the 40 tons per year increase of VOC emissions that would trigger emissions banking, New Source Review, Title V Operating Permit program, Chemical Accidental Release program, and the Conformity to SIPs designed to protect air quality and attain and maintain the NAAQS. The emissions from the proposed action are below the thresholds that would require a conformity analysis under the regulations found in $40 \mathrm{CFR}$ 51 Subpart W.

\subsection{Impact on Endangered or Threatened Species}

There is no impact on endangered and threatened species as a result of the proposed project. There are no know endangered and threatened species in or around the Big Hill Facility.

\subsection{Impact on Floodplains and Wetlands}

There is no impact on floodplains and wetlands as a result of the proposed project. The Big Hill Facility is not located in the 100-year floodplain, and there are no wetlands surrounding the facility.

\subsection{Impact on Farmland, State or National Parks, Wild and Scenic Rivers, Natural Resources}

There is no impact on farmland, State or National Parks, wild and scenic rivers, or other natural resources as a result of the proposed project. Even though the Big Hill Facility is surrounded by farmland, there will be no additional construction activities, only minor operational changes. The facility is not adjacent to a State or National Parks, wild and scenic Rivers, or other natural resources. 


\subsection{Impact on Socioeconomic Environment}

There is no impact on the socioeconomic environment as a result of the proposed project. The increase in operational conditions at the Big Hill facility as a result of this proposed project will not require a change in the workforce in the area.

\subsection{Other Impacts}

The continuous movement of crude oil in and out of the caverns will have an impact on the life cycle of the caverns. The storage caverns at Big Hill currently use fresh water to push the crude oil out of the caverns during a drawdown. As a consequence, the fresh water dissolves the salt walls of the storage cavern enlarging the storage capacity of the cavern. A complete drawdown of a storage cavern is estimated to enlarge the storage capacity by 15 percent. The storage caverns were designed for five fresh water cycles. Once the fifth cycle has occurred, the caverns no longer meet the SPR geology risk criteria for cavern separation, so the caverns must be switched to brine-driven rather than fresh water driven drawdowns. The proposed action includes the use of brine to withdraw the crude oil from the Big Hill storage caverns. The ability to use brine would start during the commercial withdrawal cycle approximately 2-3 years after the start of commercial oil fill and might necessitate the development of two new brine caverns within the Big Hill Facility. This action would be subject to further NEPA review if and when this becomes necessary.

No cumulative or long-term impacts of the proposed action have been identified. Air impacts at the facility combined with existing emissions from the facility would not exceed levels that would require a permit modification, only an amendment. The proposed action will not have any effects on public safety and health. 


\subsection{SUMMARY AND CONCLUSIONS}

The Big Hill SPR facility has been a permitted operating crude oil storage site since 1986 with benign environmental impacts. However, Congress has not authorized crude oil purchases for the SPR since 1990, and six storage caverns at Big Hill are underutilized with 70 million barrels of available storage capacity.

On February 17, 1999, the Secretary of Energy offered the 70 million barrels of available storage at Big Hill for commercial use. Interested commercial users would enter into storage contracts with DOE, and DOE would receive crude oil in lieu of dollars as rental fees. The site could potentially began to receive commercial oil in May 1999.

The proposed action is considered of mutual benefit to both industry and Government because it allows for the incremental filling of the SPR crude oil supplies for national emergency use at little public cost while providing 70 million barrels (minus negotiated rental oil) of storage space for commercial use.

The commercial use of the Big Hill SPR would be a change from the permitted current mode of SPR operations, i.e., fill, standby, and drawdown previously assessed under existing NEPA documents. Under commercialization there would be potentially more movement of crude oil, but the severity of potential environmental impacts would not increase.

This Environmental Assessment identified environmental changes that potentially would affect water usage, power usage, and air emissions. However, as the assessment indicates, changes would not occur to a major degree affecting the environment and no long-term, short-term, cumulative or irreversible impacts have been identified. 


\subsection{AGENCIES AND PERSONS CONSULTED}

Mr. John Howard

Environmental Policy Director

Governor's Policy Office

P.O. Box 12428

Austin, TX 78711

Mr. Thomas c. Adams

State Single Point of Contact

Texas Governor's Office of Budget and Planning

State Insurance Building

1100 San Jacinto, Room 274

P.O. Box 12428

Austin, TX 78711

Mr. Salvatore Bellassai

Environmental Assessment Committee Chairman

24 Wellington Court

Missouri City, TX 77459

Mr. Tom Treadway

Executive Director

General Services Commission

State Energy Conservation Office

P.O. Box 13047

Austin, TX 78711-3047

Tel: (512) 463-193

Fax: (512) 475-2569

Mr. Bobby Arp

Manager, Marketing Services

Sun Marine Terminals

P.O. Box 758

Nederland, TX 77627

Mr. Ron James

Manager, Beaumont Terminal

Unocal Corporation

P.O. Box 237

Nederland, TX 77627 


\subsection{REFERENCES}

U.S. Department of Energy, 1978c. Strategic Petroleum Reserve-Texoma Group Salt Domes, DOE/EIS-0029

U.S. Department of Energy, 1981. Strategic Petroleum Reserve-Phase III

Development, Texoma and Seaway Group Salt Domes (West Hackberry and Bryan Mound Expansion, Big Hill Development), DOE/EIS-0075

U.S. Department of Energy, 1988. Strategic Petroleum Reserve-Texoma Complex Distribution Enhancements, DOE/EA-0272

U.S. Department of Energy, 1988. Strategic Petroleum Reserve-Sulphur Mines Decommissioning and Big Hill Expansion, DOE/EA-0401 


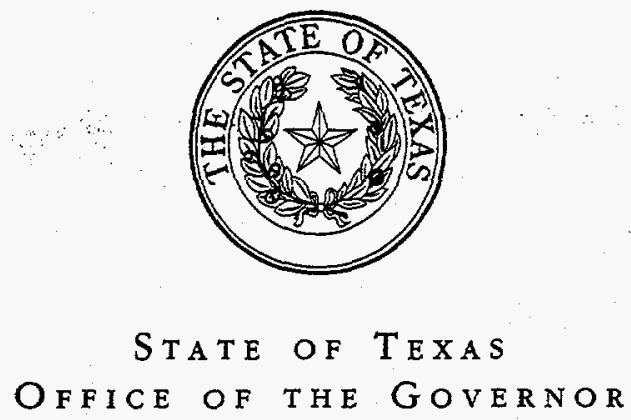

GEORGE $W$. BUSHI GOVERNOR

March 26, 1999

Mr. David Brine

U. S. Department of Energy

900 Commerce Rd. East, SPR Pro. Mgmt

New Orleans, LA 70123

RE: TX-R-19990303-0004-50-00

DRAFT EA:BIG HILL PETROLEUM RESERVE COM. STORAGE

Dear Mr. Brine:

Your environmental impact statement for the project referenced above has been reviewed. No substantive comments were received.

We appreciate the opportunity afforded to review this document. Please let me know if we can be of further assistance.

Sincerely,

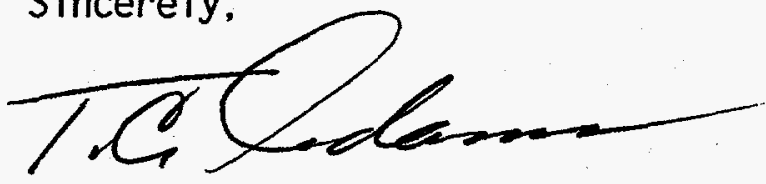

T. C. Adams, State Single Point of Contact

$\mathrm{TCA} / / \mathrm{mhr}$ 
Applicant/Originating Agency: U. S. Department of Energy

Contact Name and Phone: Mr. David Brine / (504) 734-4277

Project Title: DRAFT EA:BIG HILL PETROLEUM RESERVE COM. STORAGE

Funding Agency: DOE

SAI/EIS\#: TX-R-19990303-0004-50-00

Agency Application Identifier: EA No. 1289

Date Received: February 26, 1999

Date Comments Due BPO: 03/26/1999

REVIEW PARTICIPANTS

Texas Coastal Coordinating Council

Ms. Janet Fatheree

Secretary

Room 617, Stephen F. Austin Building

Austin, Texas 78711

Texas Natural Resource Conservation Commission

Ms. Cathy Mayes

Office of Policy \& Regulatory Dev. MC205

P. 0. Box 13087

Aust in, Texas 78711-3087

Texas Parks and Wildlife Department

Mr. Robert W. Spain, Chief

Habitat Assessment Branch

4200 Smith School Road

Austin, Texas 78744

South East Texas Regional Planning Commission

Mr. Don Kelly

Executive Director

P.0. Drawer 1387

Nederland, Texas 77627

Special Notes/Comments: Copy of environmental assessment provided by SPOC. Reviewers should contact applicant directly for additional information.

[] No Comment.

Return Comments to:

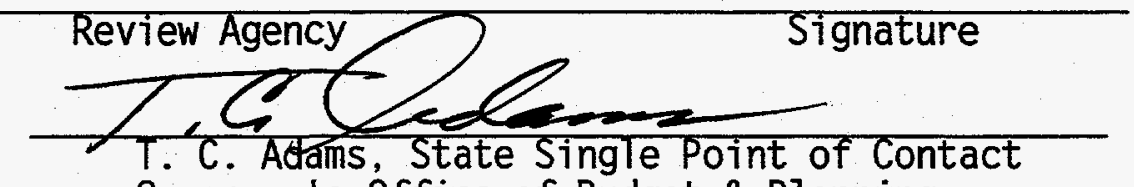
Governor's Office of Budget \& Planning P.0. Box 12428 Austin, TX 78711 (512) $463-1771$ 